\title{
Thrombocytopaenia with absent radius (not radii)
}

\author{
Uday Yanamandra, Kamal Kant Sahu, Pankaj Malhotra, Subhash Varma
}

Department of Hematology, Internal Medicine, PGIMER, Chandigarh, India

\section{Correspondence to}

Dr Uday Yanamandra, udayj2@gmail.com

Accepted 3 May 2014

\section{CrossMark}

To cite: Yanamandra $U$, Sahu KK, Malhotra P, et al. BMJ Case Rep Published online: [please include Day Month Year] doi:10.1136/ bcr-2014-204844

\section{DESCRIPTION}

A 13-year-old boy presented to the outpatient department with incidentally detected thrombocytopaenia. Historically, the patient had no bleeding symptoms or cow milk intolerance. Physical examination revealed hypoplastic thumbs in both hands and thinned-out right forearm (figures 1-3). $\mathrm{X}$-ray of both forearms showed absent radius on the right side with bilateral hypoplastic thumbs (figure 4A, B). Systemic examination otherwise was essentially normal. His haematological parameters revealed haemoglobin of $12.5 \mathrm{~g} / \mathrm{dL}$, total leucocytes $4900 / \mu \mathrm{L}$ and platelet counts $46000 / \mu \mathrm{L}$. Bone marrow examination revealed a reduction in thrombopoietic element (hypomegakaryocytic thrombocytopaenia) with preservation of other haematopoietic elements. Chromosomal breakage studies performed were negative.

Our patient has two unique features. One, unlike conventional cases of thrombocytopaenia with absent radius (TAR), our patient has a fully developed radius in the uninvolved side with bilateral hypoplastic thumbs. Second, the patient's elder brother was diagnosed with Fanconi's anaemia at 10 years of age with normal parents/grandparents.

TAR syndrome is characterised by normal thumbs with absent bilateral radius. It is an autosomal recessively inherited disorder with microdeletions in 1q21.1. ${ }^{1}$ Various associations reported by Greenhalg et al include lower limb involvement and lactose intolerance (particularly cow's milk) with $47 \%$ cases of each, renal anomalies (27\%) and congenital heart diseases in $15 \%$ cases. $^{2}$ Various studies evaluated thrombocytopaenia of the TAR syndrome; its suggested mechanisms include defective $\mathrm{c}-\mathrm{Mpl}$ signalling and dysmegakaryocytopoiesis

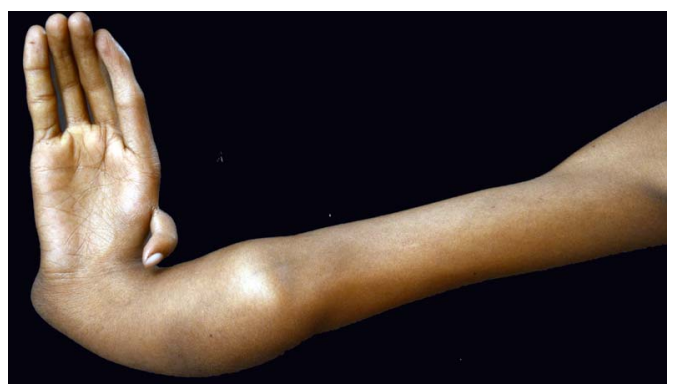

Figure 1 Palmar aspect of the right upper limb showing thinned-out forearm due to absent radius and hypoplastic thumb.

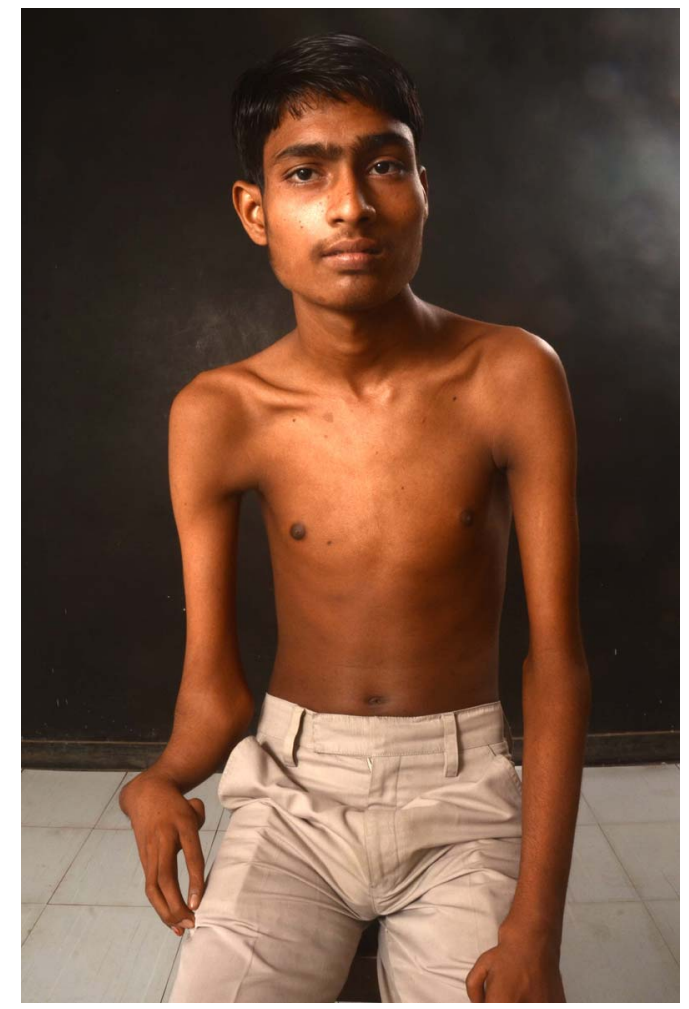

Figure 2 The right upper limb showing thinned-out forearm due to absent radius and hypoplastic thumb.

characterised by cells blocked at an early stage of differentiation. ${ }^{3}$ TAR needs to be differentiated from other syndromes such as thalidomide embryopathy, Holt-Oram syndrome, Robert syndrome and Fanconi's anaemia.

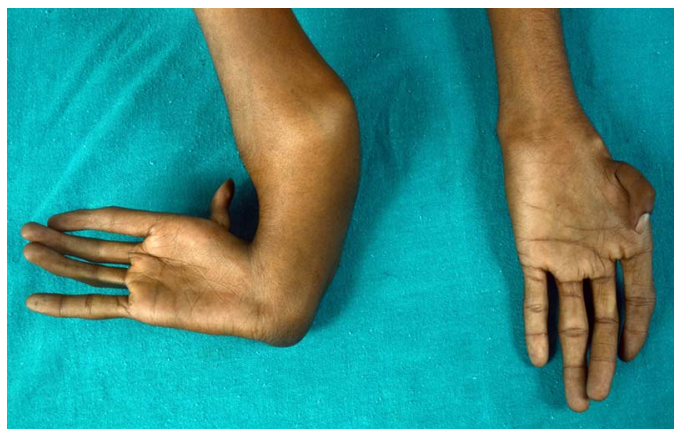

Figure 3 Comparison of the right (pathological) and left forearms and hands, both hands have hypoplastic thumbs with the left forearm having an intact well-developed radius. 
Figure 4 (A) X-ray of the right arm, forearm and hand showing absent radius and hypoplastic thumb. (B) $\mathrm{X}$-ray of the left forearm and hand showing hypoplastic thumb and an intact well-developed radius as compared with the right forearm.

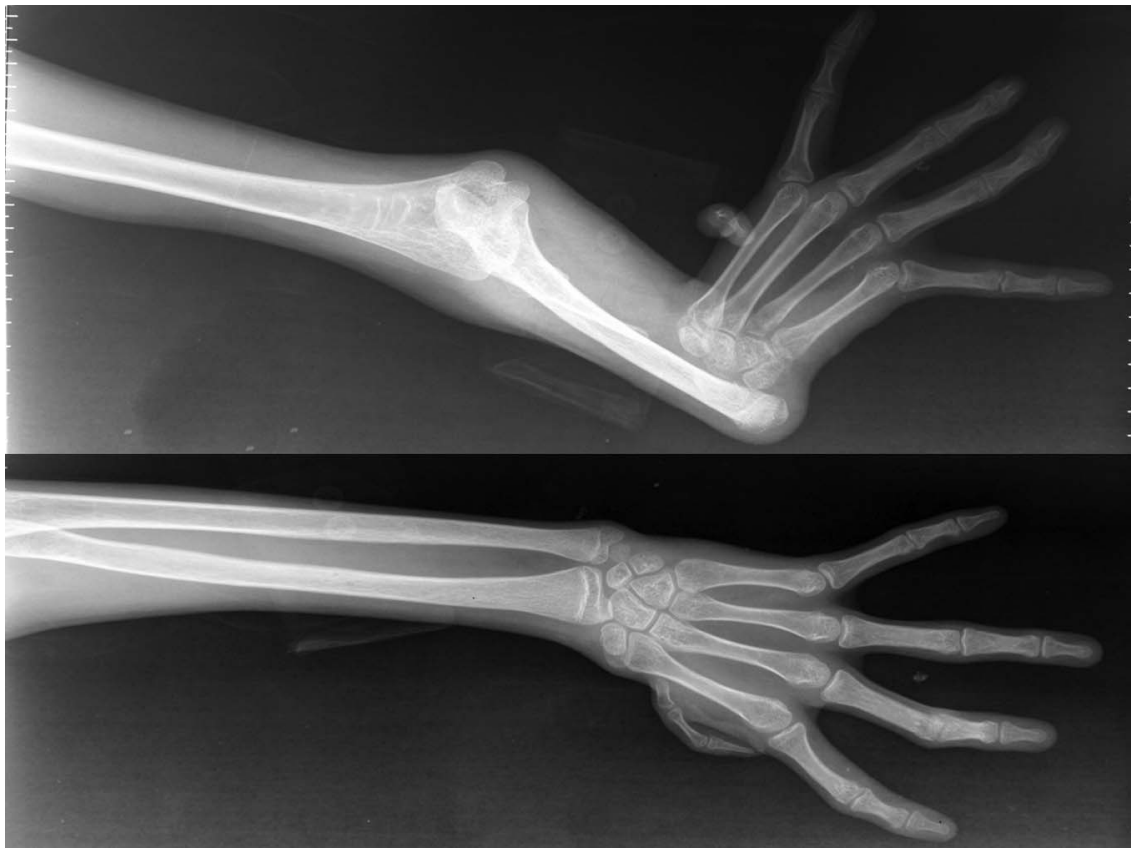

Competing interests None.

\section{Learning points}

- Thrombocytopaenia with absent radius is a rare autosomal recessive congenital disorder with bilateral absent radius.

- Congenital thrombocytopaenia is associated with a number of syndromes associated with limb anomalies.

- It is very important to perform thorough general examination for congenital anomalies in young patients with thrombocytopaenia to help in diagnosis of congenital thrombocytopaenia syndromes.

Acknowledgements The authors acknowledge the Pathology and Radiology Departments of PGIMER for their constant support.

\section{Patient consent Obtained.}

Provenance and peer review Not commissioned; externally peer reviewed.

\section{REFERENCES}

1 Klopocki E, Schulze H, Strauss G, et al. Complex inheritance pattern resembling autosomal recessive inheritance involving a microdeletion in thrombocytopenia-absent radius syndrome. Am J Hum Genet 2007:80:232-40.

2 Greenhalgh KL, Howell RT, Bottani A, et al. Thrombocytopenia-absent radius syndrome: a clinical genetic study. J Med Genet 2002;39:876-81.

3 Letestu R, Vitrat N, Massé A, et al. Existence of a differentiation blockage at the stage of a megakaryocyte precursor in the thrombocytopenia and absent radii (TAR) syndrome. Blood 2000;95:1633-41.

Copyright 2014 BMJ Publishing Group. All rights reserved. For permission to reuse any of this content visit

http://group.bmj.com/group/rights-licensing/permissions.

BMJ Case Report Fellows may re-use this article for personal use and teaching without any further permission.

Become a Fellow of BMJ Case Reports today and you can:

- Submit as many cases as you like

- Enjoy fast sympathetic peer review and rapid publication of accepted articles

- Access all the published articles

- Re-use any of the published material for personal use and teaching without further permission

For information on Institutional Fellowships contact consortiasales@bmjgroup.com

Visit casereports.bmj.com for more articles like this and to become a Fellow 